\title{
PENILAIAN KONSUMEN TERHADAP PRODUK SUSU CAIR PADA SUSU ULTRA MILK DAN CIMORY
}

\author{
Stephen Pratama \\ Program studi Magister Manajemen Universitas Tarumanagara \\ Stephen.pratama93@yahoo.co.id \\ Chairy \\ Program studi Magister Manajemen Universitas Tarumanagara
}

\begin{abstract}
With the increasing level of milk consumption in Indonesia, such as Indonesia's population of 252 million, the level of consumption of dairy products will increase the nutritional needs. Ultramilk Milk is the dominant dairy market $(40 \%$ in Indonesia and milk cimory is a newcomer) Ultramilk survivors using Ultra High Technology (UHT) technology that is more durable milk does not have the required content value whereas milk from cimory uses pasturative milk is milk rich in nutrients can not last long. Any benefits of milk will be mixed to create the best design when you want to make a dairy factory. Characteristics (similarities and differences) Freshness, Nutrition, Brand Image, process and packaging in UltraMilk Milk and Milk Ultramilk cimory is just superior in taste After indicator $(0.042<0.05)$ in the Freshness variable. Milk Cimory Milk excels in 23 other indiactors such as ketaduasa, aroma of milk, milk taste, milk color, no impurities, net value information, composition information, calorie information, carbohydrate information, fat information, protein information, vitamin information, mineral information, water content, image, Koorporat image, product image, user image, process temperature, protein content, exposure time, flavor variant, variant size and packaging form with the highest value possessed by kimory milk is protein content in milk beverage in the process. (Pasturation) is also caused by the community has begun to understand and understand that milk pasturization is better in consumption compared to UHT Milk Consumer's assessment of Freshness, Nutrition, Brand Image, Process and packaging on UltraMilk and Cimory Milk is only superior to variable Freshness (Freshness) through the Sense of Milk indicator (4.1504 > 4.0708). Ultra milk is superior to nutrition (nutrition) just about the information Protein is given (4.0354 > 4.0177). For Ultramilk Brand Image has no advantages compared to CimoryMilk In UltraMilk Ultra Milk Processing (Process) also does not have any advantages compared to CimoryMilk. For the Ultramilk Package indicator only superior for the Variable size indicator $(3.8053>3.7876)$.
\end{abstract}

Abstrak: Dengan meningkatnya tingkat konsumsi susu di Indonesia, seperti penduduk Indonesia sebesar 252 juta, tingkat konsumsi produk susu akan meningkatkan kebutuhan gizi. Susu Ultramilk adalah pasar susu yang dominan (40\% di Indonesia dan susu cimory adalah pendatang baru) Penyintas Ultramilk menggunakan teknologi Ultra High Technology (UHT) yang lebih tahan lama susu tidak memiliki nilai konten yang dibutuhkan sedangkan susu dari cimory menggunakan susu pasturatif adalah susu kaya nutrisi tidak bisa bertahan lama. Setiap manfaat susu akan dicampur untuk menciptakan desain terbaik ketika Anda ingin membuat pabrik susu. Karakteristik (persamaan dan perbedaan) Kesegaran, Nutrisi, Citra Merek, proses dan pengemasan dalam UltraMilk Milk and Milk Ultramilk cimory hanya unggul dalam rasa Setelah indikator $(0,042<0,05)$ dalam variabel Kesegaran. Susu Cimory Milk unggul dalam 23 indiactors lainnya seperti ketaduasa, aroma susu, rasa susu, warna susu, tidak ada kotoran, informasi nilai bersih, 
informasi komposisi, informasi kalori, informasi karbohidrat, informasi lemak, informasi protein, informasi vitamin, informasi mineral, kadar air, citra, citra Koorporat, citra produk, citra pengguna, suhu proses, kadar protein, waktu pemaparan, varian rasa, ukuran varian dan bentuk kemasan dengan nilai tertinggi yang dimiliki oleh susu kimory adalah kandungan protein dalam minuman susu dalam prosesnya. (Pasturation) juga disebabkan oleh masyarakat telah mulai memahami dan memahami bahwa pasturisasi susu lebih baik dalam konsumsi dibandingkan dengan penilaian Konsumen Susu UHT tentang Kesegaran, Nutrisi, Citra Merek, Proses dan pengemasan pada UltraMilk dan Cimory Milk hanya unggul untuk Kesegaran Variabel (Kesegaran) melalui indikator Sense of Milk (4.1504> 4.0708). Susu ultra lebih unggul untuk nutrisi (nutrisi) hanya tentang informasi Protein diberikan (4.0354> 4.0177). Untuk Citra Merk Ultramilk tidak memiliki kelebihan dibandingkan dengan CimoryMilk Dalam UltraMilk Ultra Milk Processing (Process) juga tidak memiliki kelebihan dibandingkan dengan CimoryMilk. Untuk indikator Paket Ultramilk hanya unggul untuk indikator ukuran Variabel $(3,8053>$ 3,7876).

Keywords : Milk, Independent t-test,UltraMilk,Cimory, Freshness,Nutrition, Brand Image, Process, Package.

\section{PENDAHULUAN}

Banyaknya pertumbuhan yang terjadi pada penduduk indonesia mengakibatkan Berkembangnya konsumsi minum susu yang menjadi sumber kalsium bagi pertumbuhan seseorang. Jumlah penduduk Indonesia yang mencapai 270 juta jiwa penduduk menjadi lahan bisnis yang sangat potensial bagi perusahaan-perusahaan untuk memproduksi dan menawarkan produk unggulannnya kepada konsumen, salah satunya adalah produk minuman susu baik susu cair maupun susu bubuk. Bermunculannya produk minuman susu dengan berbagai merek yang beredar di masyarakat saat ini mengakibatkan terciptanya persaingan yang kompetitif antar perusahaan tersebut. Ini mendorong perusahaan untuk selalu melakukan berbagai strategi pemasaran agar dapat bertahan dalam arus persaingan bisnis sehingga perusahaan dituntut untuk mampu memilih strategi pemasaran yang tepat. Suatu perusahaan dapat menjadi pemenang dalam persaingan bisnis yang semakin ketat apabila perusahaan mampu menarik konsumen sebanyakbanyaknya dan tentu perusahaan juga dapat memperoleh keuntungan yang besar sesuai tujuan dari perusahaan tersebut.

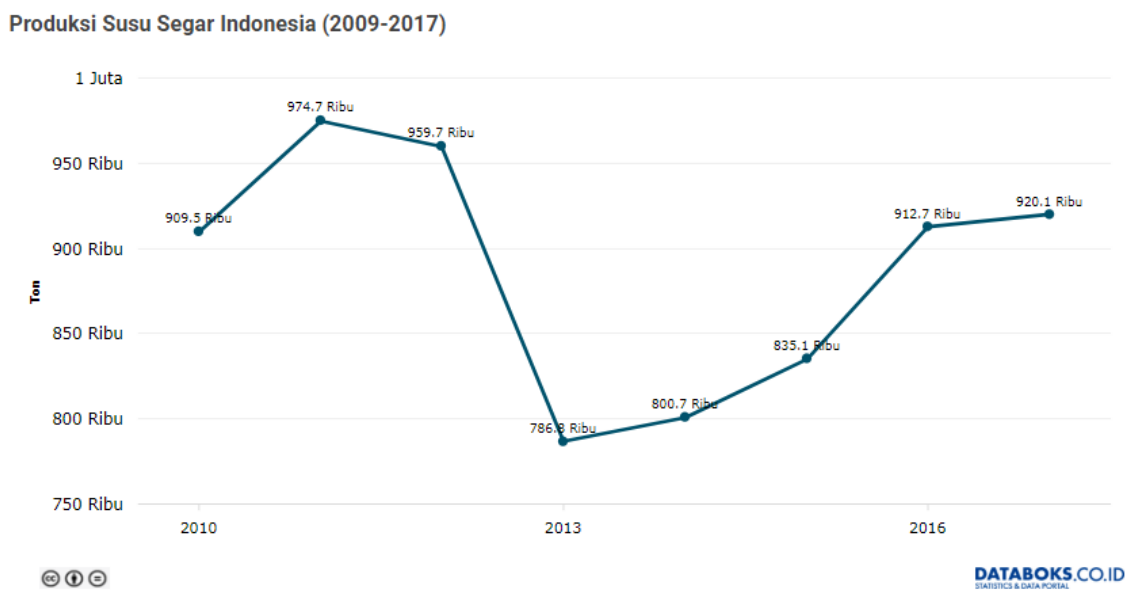

Gambar 1 Volume konsumsi susu Indonesia (dalam Ton ) (Sumber : Databoks.co.id ) 
Tingkat konsumsi susu di Indonesia masih tergolong rendah dibandingan beberapa negara lain, namun secara signifikan telah mengalami peningkatan bertahap di beberapa tahun terakhir.

Data pertumbuhan volume konsumsi susu dari tahun 2008-2013, Konsumsi susu di Indonesia dari tahun 2008-2013 terus mengalami peningkatan sebesar 8,3\%. Kemudian, tahun 2014-2018 konsumsi produk susu di Indonesia diprediksi akan terus meningkat sebesar 7,0\%. Data tersebut menunjukkan adanya peluang yang besar bagi industri pengolahan susu Indonesia untuk terus mengembangkan bisnisnya. Peluang yang baik dalam bisnis industri pengolahan susu juga diperkuat dengan adanya berbagai program yang bertujuan meningkatkan jumlah konsumsi susu bagi masyarakat Indonesia. Program tersebut dilaksanakan melalui peningkatan peran pengusaha susu yang telah disusun oleh 14 lembaga pemerintah bekerja sama dengan tiga asosiasi industri pengolahan susu (Herawati dan Priyanto, 2013)

Menurut Morey (2011), tahun 2009 terdapat 31 perusahaan yang beroperasi pada industri susu cair di Indonesia dengan total produksi 282.100 ton. Ultra Jaya, Frisian Flag, Indolakto, dan Nestle merupakan empat perusahaan terbesar dalam industri pengolahan susu cair. Keadaan ini menunjukkan bahwa prospek bisnis susu sangat baik. Namun, terdapat tantangan yang cukup besar dalam pemasaran produknya. Banyaknya jumlah perusahaan yang beroperasi dalam bidang pengolahan susu menyebabkan persaingan yang ketat karena konsumen dibanjiri berbagai merek produk susu cair.

\section{TUJUAN PENELITIAN:}

- Mendeskripsikan karakteristik (persamaan dan perbedaan) Kesegaran, Nutrisi, Brand Image, Proses dan kemasan pada Susu UltraMilk dan Cimory?

- Menjelaskan penilaian konsumen terhadap Kesegaran, Nutrisi, Brand Image, Proses dan kemasan pada Susu UltraMilk dan Cimory?

\section{TELAAH KEPUSTAKAAN:}

Menurut Saleh (2011), Susu segar merupakan cairan yang berasal dari kambing atau sapi yang sehat dan bersih. Susu diperoleh dengan cara pemerahan yang benar dan kandungan alaminya tidak dikurangi, atau ditambah sesuatu apapun dan belum mendapat perlakuan apapun. Selain itu, susu segar yang baik adalah belum mengalami perubahan warna, rasa, kekentalan, bau, berat jenis, kekentalan, titik beku, titik didih dan tingkat keasamannya.

Menurut BSN (1998), susu murni adalah cairan yang berasal dari ambing sapi sehat dan bersih, yang diperoleh dengan cara

pemerahan yang benar, yang kandungan alaminya tidak dikurangi atau ditambah sesuatu apapun dan belum mendapat perlakuan apapun. Buckle et al. (1987) menyebutkan bahwa komposisi susu sangat beragam dan tergantung pada beberapa faktor, tetapi angka rata-rata untuk semua jenis dan kondisi susu adalah lemak $3.90 \%$, protein $3.40 \%$, laktosa $4.80 \%$, abu $0.72 \%$, dan air $87.10 \%$. Susu adalah emulsi dari globular lemak dalam air. Di dalam lemak susu terdapat vitamin larut lemak A, D, E, K. Masing-masing globula dikelilingi membran fosfolipid yang mempertahankan butiran lemak susu dan untuk melindungi pemecahan globula oleh enzim-enzim lipid yang ada dalam susu. 
Pasteurisasi adalah perlakuan panas yang diberikan pada bahan baku dengan suhu di bawah titik didih, yaitu pemanasan di bawah $100^{\circ} \mathrm{C}$. Standar pasteurisasi menggunakan suhu $62-66^{\circ} \mathrm{C}$ selama 30 menit, atau pada suhu $71^{\circ} \mathrm{C}$ selama 15 detik.

Pada metode HTST susu dipanaskan selama 16-15 detik menggunakan alat pemanas berbentuk lempengan (plate type heat exchanger) pada suhu $71,7-75^{\circ} \mathrm{C}$. sedangkan pasteurisasi dengan metode LTLT, susu dipanaskan pada suhu $65^{\circ} \mathrm{C}$ selama 30 menit (Asmita, 2009).

Susu UHT merupakan susu yang sangat higienis, karena bebas dari seluruh mikroba (patogen/penyebab penyakit dan pembusuk), serta spora, sehingga potensi kerusakan mikrobiologis sangat minimal, bahkan hampir tidak ada. Kontak panas yang sangat singkat pada proses UHT, yaitu tidak kurang dari $135{ }^{\circ} \mathrm{C}$ selama 2 detik menyebabkan mutu sensori (warna, aroma dan rasa khas susu segar) dan mutu zat gizi, relatif tidak berubah. Susu UHT dikemas dengan enam (6) lapis kertas, plastik polyethylene, dan alumunium foil yang mampu melindungi susu dari udara luar, cahaya, kelembaban, aroma luar dan bakteri. Susu UHT dalam kemasan aseptik ini tahan disimpan dalam suhu kamar sampai 10 bulan, tanpa bahan pengawet. Dengan kemasan tersebut, susu terhindar dari bakteri perusak minuman dan tetap segar, serta aman untuk dikonsumsi (Hariyadi, 2011).

\section{METODOLOGI:}

Jenis penelitian yang digunakan dalam penelitian "Analisis Perbandingan Produk Susu Cair Melalui Faktor Kesegaran, Nutrisi, Brand Image, Proses, dan Kemasan pada Susu UltraMilk dan Cimory berdasarkan Penilaian Konsumen" adalah penelitian deskriptif dengan metode kuantitatif. Sugiyono (2008: 13) menyampaikan bahwa,Penelitian deskriptif merupakan penelitian yang bertujuan untuk menggambarkan fenomena tertentu secara spesifik. Penelitian ini terkadang dilakukan tanpa merumuskan hipotesis, kalaupun terdapat hipotesis tetapi tidak untuk diuji melalui statistik (Singarimbun \& Effendi, 1995: 4-5).

\begin{tabular}{|c|c|c|}
\hline Variabel & Definisi & Indikator \\
\hline \multirow{3}{*}{ Freshness } & \multirow{3}{*}{ Susu segar adalah susu murni, tidak mengalami pemanasan, dan tidak ada penambahan bahan pengawe } & ExpairedDate \\
\hline & & Aroma \\
\hline & & $\frac{\text { Taste }}{\text { After Consumption }}$ \\
\hline \multirow{4}{*}{ Nutrition } & \multirow{4}{*}{ nutrisi adalah apa yang terkandung dalam makanan tersebut } & Fat Content \\
\hline & & \\
\hline & & Indgredients \\
\hline & & Calories \\
\hline \multirow[b]{2}{*}{ Brand Image } & \multirow{2}{*}{$\begin{array}{c}\text { Persepsi dan kepercayaan yang dipegang oleh konsumen, yang tercermin atau } \\
\text { melekat dalam benak dan memori dari seorang konsumen sendiri. Persepsi ini } \\
\text { dapat terbentuk dari informasi atau pengalaman masa lalu konsumen terhadap } \\
\text { merek tersebut. Kotler \& Keller (2012:Gi) }\end{array}$} & $\frac{\text { Attribute }}{\text { Manfat }}$ \\
\hline & & Evaluasi Keseluruhan \\
\hline \multirow{3}{*}{ Processing } & \multirow{3}{*}{$\begin{array}{l}\text { Persepsi dan kepercayaan yang dipegang oleh konsumen, yang tercermin atauproses adalah serangkaian langkah sistematis, atau tahapan yang jelas dan dapat } \\
\text { ditempuh berulangkali, untuk mencapai hasil yang dinginkan. Jika ditempuh, setiap tahapan itu secara konsisten mengarah pada hasil yang diinginkan. }\end{array}$} & Suhu \\
\hline & & Kandungnan Frotein \\
\hline & & Durability \\
\hline \multirow{3}{*}{ Package } & \multirow{3}{*}{$\begin{array}{l}\text { proses kemasan melibatkan kegiatan mendesain dan memproduksi, fungsi } \\
\text { utama dari kemasan sendiri yaitu untuk melindungi produk agar produk tetap } \\
\text { terjaga kualitasnya. }\end{array}$} & Variant Rasa \\
\hline & & Varuant Ukuran \\
\hline & & Variant Bnetuk Kemasan \\
\hline \multicolumn{3}{|c|}{ Source: Adapted from Northen (2000), Caswell et al. (1998) and Bruhn et al. (2005). } \\
\hline \multicolumn{3}{|c|}{ Fromm ind Boor (2004). } \\
\hline \multirow{2}{*}{\multicolumn{3}{|c|}{ 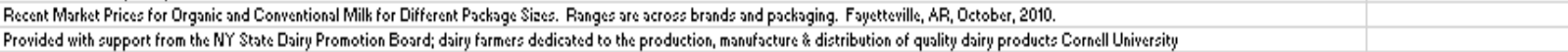 }} \\
\hline & & \\
\hline \multirow{2}{*}{\multicolumn{2}{|c|}{$\begin{array}{l}\text { Sumber: Waletro et al. (2006) } \\
\text { Sumber : Sctiswon don Tonius } 2\end{array}$}} & \\
\hline & & \\
\hline
\end{tabular}

Sampel yang diambil sebagai responden dari penelitian ini adalah 113 anggota komunitas anak muda (Mahasiswa/i) Universitas yang mengkonsumsi minum Susu Cair Ultra Milk dan Cimory, Jakarta. 
Peneliti mengambil 113 orang responden dengan melihat jumlah anggota komunitas anak muda ( Mahasiswa/i) Universitas di Jakarta. Peneliti akan memilih 113 orang responden secara purposive. Menurut Sugiyono (2008: 122), dalam teknik sampling purposive, sampel dipilih oleh peneliti dengan kriteria tertentu. Kriteria yang diinginkan oleh peneliti dalam memperoleh responden adalah anggota komunitas anak muda (Mahasiswa/i) Universitas Jakarta yang mengkonsumsi susu cair UltraMilk dan Cimory baik mendapatkanya di alfamart, Indomaret, Cimory Store dan media online. Setiap responden akan menjawab pertanyaan demi pertanyaan di mana dalam setiap pertanyaan, responden harus memberikan penilaian untuk Ultra Milk dan Cimory Milk.

\section{PEMBAHASAN dan HASIL PENELITIAN:}

Berdasarkan hasil t-test yang ada di dapatkan hasil bahwa untuk indikator keterangan waktu kadaluasa $(0.472>0.05)$ yang berarti Terima Ho menyatakan bahwa indikator waktu kadaluasa pada susu cimory lebih baik dari pada Susu Ultramilk untuk varibel kesegaran ( Freshness). Untuk Indikator Aroma Susu (0.095>0.050) yang berarti Terima H0,Rasa Susu $(0.208>0.050)$ yang berarti terima H0 , Rasa yang tertinggal $(0.042<$ $0.050)$ yang berarti terima H0, Warna Susu $(0.393>0.050)$ yang berarti tolak H0, Tidak terdapatnya kotoran $(0.442>0.050)$ yang berarti terima H0, Informasi Nilai Bersih $(0.672>0.050)$ yang berarti terima H0, Informasi komposisi $(0.795>0.050)$ yang berarti terima H0, Informasi Kalori $(0.414>0.050)$ yang berarti terima H0, Informasi Karbohidrat $(0.943>0.050)$ yang berarti terima H0, Informasi Lemak $(0.881>0.050)$ yang berarti terima H0, Informasi Protein $(0.791>0.050)$ yang berarti terima H0, Informasi Vitamin $(0.634>0.050)$ yang berarti terima H0, Informasi Mineral $(0.796>$ $0.050)$ yang berarti terima H0, Informasi Kandungan air $(0.555>0.050)$ yang berarti terima H0, Citra koorporat $(0.866>0.050)$ yang berarti terima H0, Citra Produk $(0.316>$ $0.050)$ yang berarti terima H0, Citra Pemakai $(0.518>0.050)$ yang berarti terima H0, Suhu Proses $(0.655>0.050)$ yang berarti terima H0, Kandungan Protein $(0.988>0.050)$ yang berarti terima H0, Waktu Kadaluasa $(0.465>0.050)$ yang berarti terima H0, Variant rasa $(0.331>0.050)$ yang berarti terima $\mathrm{H} 0$, Ukuran variant $(0.276>0.050)$ yang berarti terima H0,Bentuk Kemasan $(0.140>0.050)$ yang berarti terima H0.

Berdasarkan hasil Rata-rata dari penilaian konsumen didapatkan bahwa untuk indikator keterangan waktu kadaluasa,Ultra lebih kecil di bandingakan dengan Susu Cimory (3.9823 <4.1062). Aroma susu ,Ultra lebih kecil di bandingakan dengan Susu Cimory (3.6726 <4.0796). Rasa Susu ,Ultra lebih besar di bandingakan dengan Susu ultra Cimory (4.1504 >4.0708). Rasa yang tertinggal Ultra lebih kecil di bandingakan dengan Susu ultra Cimory (3.6283 <3.8584).Warna Susu Ultra lebih kecil di bandingakan dengan Susu ultra Cimory (3.6195 <3.9292). Tidak Terdapatnya kotoran Ultra lebih kecil di bandingakan dengan Susu ultra Cimory (3.9912 <4.1858).Informasi Nilai Bersih Ultra lebih kecil di bandingakan dengan Susu ultra Cimory (4.0000 <4.1150).Informasi Komposisi Ultra lebih kecil di bandingakan dengan Susu ultra Cimory (3.9469 44.0442).Informasi Kalori Ultra lebih kecil di bandingakan dengan Susu ultra Cimory (3.9823 <4.0442).Informasi Karbohidrat Ultra lebih kecil di bandingakan dengan Susu ultra Cimory (3.9735 <4.0796).Informasi Lemak Ultra lebih kecil di bandingakan dengan Susu ultra Cimory (4.0177 <4.0973). 
Informasi Protein Ultra lebih besar di bandingakan dengan Susu ultra Cimory (4.0354 >4.0177).Informasi Vitamin Ultra lebih kecil di bandingakan dengan Susu ultra Cimory (3.9292 44.0354).Informasi Mineral Ultra lebih kecil di bandingakan dengan Susu ultra Cimory (3.9469 44.0354).Informasi Kandungan air Ultra lebih kecil di bandingakan dengan Susu ultra Cimory (3.8053 <4.0000).Citra koorporat Ultra lebih kecil di bandingakan dengan Susu ultra Cimory (3.6903 <3.9027).Citra Produk Ultra lebih kecil di bandingakan dengan Susu ultra Cimory (3.7434 <3.9381).Citra Pemakai Ultra lebih kecil di bandingakan dengan Susu ultra Cimory (3.6991 <3.9381).Suhu Proses Ultra lebih kecil di bandingakan dengan Susu ultra Cimory (3.9115 $<4.0708$ ).Kandungan Protein Ultra lebih kecil di bandingakan dengan Susu ultra Cimory (3.9381 44.0708). Waktu kadaluasa Ultra lebih kecil di bandingakan dengan Susu ultra Cimory $(3.9027<4.0531)$.Variant Rasa Ultra lebih kecil di bandingakan dengan Susu ultra Cimory $(3.7788<4.1239)$.Ukuran Variant Ultra lebih besar di bandingakan dengan Susu ultra Cimory (3.8053 >3.7876).Bentuk Kemasan Ultra lebih kecil di bandingakan dengan Susu ultra Cimory $(3.5841<3.9204)$.

Karakteristik (persamaan dan perbedaan) Kesegaran, Nutrisi, Brand Image, Proses dan kemasan pada Susu UltraMilk dan Cimory yaitu bahwa Susu Ultramilk hanya unggul di indikator After taste $(0.042<0.05)$ dalam variabel Freshness. Sedangkan Susu Cimory Milk unggul dalam 23 indiaktor lainya sepeti keterangan kadaluasa, aroma susu, rasa susu, warna susu, tidak terdapat kotoran, informasi nilai bersih, informasi komposisi, informasi kalori, informasi karbohidrat, informasi lemak, informasi protein, informasi vitamin, informasi mineral, informasi kandungan air, Citra Koorporat, Citra Produk, Citra pemakai, Suhu proses, kandungan protein, waktu kadaluasa, variant rasa, ukuran variant dan bentuk kemasan dengan

nilai yang paling tinggi di miliki oleh cimory milk adalah kandungan Protein yang ada pada minuman susu di akibatkan proses yang terjadi (Pasturation) juga yang di sebabkan oleh

masyarakat sudah mulai mengerti dan memahami bahwa susu pasturation lebih baik di konsumsi di bandingkan dengan Susu UHT. Hal Ini harus sangat di waspadai oleh susu Ultramilk dan mnejadi dasar dalam expansi untuk produk turunan ke depan jika tidak mau di gulingkan dari market leader.

Penilaian konsumen terhadap Kesegaran, Nutrisi, Brand Image, Proses dan kemasan pada Susu UltraMilk dan Cimory adalah Susu Ultra milk hanya unggul pada variabel Freshness ( Kesegaran) melalui indikator Rasa Susu. Ultra milk unggul untuk nutrition (nutrisi) hanya tentang informasi Protein yang di berikan. Untuk Brand Image Ultramilk tidak mempunyai keunggulan di bandingkan dengan CimoryMilk Pada Process (Proses) pembutan susu juga UltraMilk tidak mempunyai keunggulan di bandingkan dengan CimoryMilk. Untuk indikator Package Ultramilk hanya unggul untuk indikator ukuran Varibel.

\section{REKOMENDASI:}

Saran-saran yang dapat diberikan sebagai masukan dan pertimbangan bagi perusahaan antara lain sebagai berikut :

Saran Praktis

Untuk Perusahaan UltraMilk:

- Mulai bermain di areh susu Pasturation yang memimili nilai kalsium lebih besar dikarenakan orang-orang sudah mulai mengerti dan di edukasi tentang susu.

- Mulai menambah Rasa Susu yang sudah ada tidak hanya Taro dan Karamel saja, tapi rasa pisang, greentea dll. 
- Membuat Bentuk- bentuk kemasan yang baru yang lebih menarik seperti dalam kemasan botol dan bukan hanya karton.

- Menemukan Strategi bagaimana susu Pasturation bisa juga bertahan dalam waktu yang lama sama seperti UHT.

. Untuk Perusahaan CimoryMilk:

- Sudah benar mengeluarkan kemasan kecil seperti yang di lakukan kompetitor UltraMilk.

- Lakukan terus edukasi sehingga masyarakat akan semakin mengerti tentang kandungan yang di dapat dalam susu.

- Melakukan penjualan susu di market yang lebih besar seperti di gerai-gerai yang belum di masukin seperti di MOR, kantin Universitas, vending machine yang ada di jalan-jalan.

Saran Akademis

1. Melakukan Uji di kemudian hari dengan menambahkan variabel yang lebih banyak.

2.Melakukan Uji Untuk menambahkan Responden yang lebih banyak.

\section{DAFTAR PUSTAKA}

Asmita, P. W. (2009). Analisis Pengaruh Pasien Tentang Mutu Pelayanan Dokter terhadap Loyalitas Pasien di Poliklinik Umum Instalasi Rawat Jalan Rumah Sakit Panti Wilasa Citarum Semarang. Tesis Magister Ilmu Kesehatan Masyarakat.Program Pasca Sarjana Universitas Diponegoro: Semarang.

Badan Standardisasi Nasional. 1995. SNI 01-3951-1995 Susu Pasteurisasi. Jakarta.

Badan Standardisasi Nasional. Susu Segar. 1998. SNI 01-3141-1998. Jakarta.

BSN (Badan Standarisasi Nasional) (1998). SNI 01-2984-1998 Tentang Minuman Squash. Jakarta: Badan Standarisasi Nasional. Hal. 1-5.

Buckle,K.A.,1987. Ilmu Pangan. Universitas Indonesia Press.Jakarta.

Hadiwiyoto, S. (1983). Penanganan dan Pemanfaatan Sampah. Yayasan Idayu. Jakarta

Hariyadi, 2011 ." Kimia danTeknologi Pati“ (Manuskripi Bahan Pengajaran), Yogjakarta : PPS UGM Press.

Herawati, H. 2012. Teknologi Proses Produksi Food Ingredient Dari Tapioka Termodifikasi. Jurnal Litbang Pertanian (31): 68-76.

Herawati, Rosita, F. 2013. Pembelajaran Kimia Berbasis Multipel Representasi Ditinjau Dari Kemampuan Awal Terhadap Prestasi Belajar Laju Reaksi Siswa SMA Negeri 1 Karang Anyar Tahun Pelajaran 2012/2013. Jurnal Pendidikan Kimia. Semarang: Universitas Sebelas Maret.

Morey 2011, An analytical Confidence Interval for the Treynor Index: Formula, Condition and Properties, Journal Of Business Finance and Accounting, 27 (1) \&(2), January/march 2001

Saleh, K.N.B. 2011. Prevalensi Penderita Penyakit Paru Obstruksi Kronis (PPOK) dengan Riwayat Merokok di Rumah Sakit Umum Pusat Haji Adam Malik (RSUP HAM) Medan Periode Januari 2009 -Desember 2009. (KTI). Universitas Sumatera Utara. Medan.

Setiawati dan S. Rahayu. 1992. Buku Teknik dan Pengembangan Peternakan Seri: Penanganan Susu. Dirjen Peternakan. Direktorat Bina Produksi Peternakan. Jakarta Pusat.

Singarimbun, Masri; Effendi, Sofian (1995). Metode Penelitian Survai. Jakarta: LP3ES.

Sugiyono (2008). Metode Penelitian Bisnis (Pendekatan Kuantitatif, Kualitatif, dan $R \& D)$. Bandung: Alfabeta. 
